ENTREPRENEURSHIP AND SUSTAINABILITY ISSUES

ISSN 2345-0282 (online) http://jssidoi.org/jesi/ 2019 Volume 7 Number 1 (September)

http://doi.org/10.9770/jesi.2019.7.1(42)

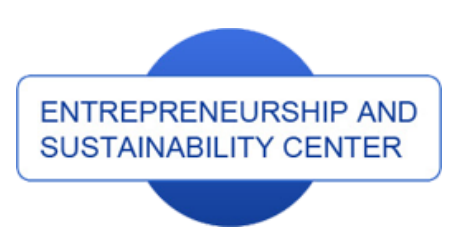

Publisher

http://jssidoi.org/esc/home

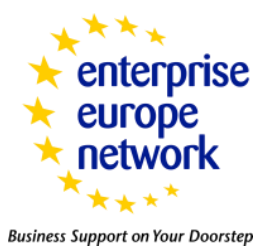

CASPA

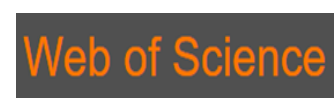

1) Clarivate

\title{
MODERN CLUSTERS AND ASSESSMENT OF THEIR INNOVATIVE DEVELOPMENT
}

\author{
Lyudmila Kostygova $^{1}$, Elena Sidorova ${ }^{2}$, Natalia Vikhrova ${ }^{3}$ \\ ${ }^{1-3}$ National University of Science and Technology MISiS, Moscow, Russia \\ E-mails: ${ }^{1}$ kostygova.lyudmila@mail.ru ; ${ }^{2}$ ejsidorova@yandex.ru $;{ }^{3}$ vihrova.no@misis.ru
}

Received 24 February 2019; accepted 15 July 2019; published 30 September 2019

\begin{abstract}
The goal of the research is to identify clusters' improvement areas in order to increase their innovativeness and to form a system of indicators for the quantitative characteristics of the proposed activities. Main results. The main directions for improving clusters in order to increase their innovativeness have been identified. The system of indicators characterizing these areas has also been proposed. Main conclusions. The use of the proposed directions and measures aimed at improving clusters and the recommended system of indicators for assessing their innovative development allowed proving a high level of innovation (using the example of the Russian titanium cluster).
\end{abstract}

Keywords: clusters; innovative development; directions and indicators for assessing clusters' innovativeness

Reference to this paper should be made as follows: Kostygova, L.; Sidorova, E.; Vikhrova, N. 2019. Modern clusters and assessment of their innovative development, Entrepreneurship and Sustainability Issues 7(1): 603-614. http://doi.org/10.9770/jesi.2019.7.1(42)

JEL Classifications: 032

\section{Introduction}

At present, there is a rich theoretical and practical knowledge in using the territorial approach in various countries' economy (Marshall, 1983, p. 128; Porter, 2005, pp. 258-269). This allowed creating modern theories of territorial development and forming new types of industrial management including clusters.

Practically all modern industry in Denmark, Finland, Norway, Sweden and other coutries is based on clusters. For instance, 380 American clusters amounted to $60 \%$ of the country's GDP. In the EU countries, there are more than 2 thousand clusters which employ 38\% of labor force (Davidenko, 2013, p. 180). One of the first, most successful and well-known clusters is Silicon Valley (the USA) that includes approximately 87 thousand companies, 40 research centers and 10 universities. It is served by 180 venture companies and 747 banks (Lenchuk, n.d.). 
The Research Institute of the Finnish Economy (ELTA) recorded 9 clusters which specialize in forest sector, metallurgy, mechanical engineering, construction engineering sector and telecommunications industry. Their activity allowed the country, in which $1 \%$ of the world's forest resources are concentrated, to provide $25 \%$ of paper exports and $10 \%$ of wood conversion products in the world (Oulu Region - The Direction for Expertise, 2003 , p. 24). Italian clusters currently provide up to $30 \%$ of the country's industrial exports. There are more than 60 cluster zones in China, including 30 thousand firms with annual revenues of $\$ 200$ billion and personnel of more than 3.5 million people. German chemical and engineering clusters, as well as French ones, that unite more than 60 thousand firms with more than 1 million employees, are actively involved in the EU clustering process (e.g. "Pegasus", a French aerospace cluster) (Abashkin, n.d.).

In the EU countries, much attention is paid to the implementation of cluster policy at various levels (local, regional, state and international). For that purpose, special organizations have been created in the EU to identify and disseminate positive clustering results.

The EU Cluster Research Commission manage a lot of work in this direction: a cluster platform (Cluster-IP) has been developed and is operating, a number of studies have been carried out, including the Cluster Policy in Europe (Oxford Research, Europe INNOVA Cluster Mapping Project and others). Thirty-one European countries and their cluster initiatives have been studied. This allowed identifying the structure, activities, terms and implementation mechanisms, sources of financing, as well as other patterns of the EU economy clustering process (Kutsenko, 2015).

The data on the cluster financing programs in Europe is presented in Figure 1. The conducted researches have shown that the main financial costs were carried out by state (national ministries) and interstate structures (the European Structural Fund), with business and regional structures’ participation.

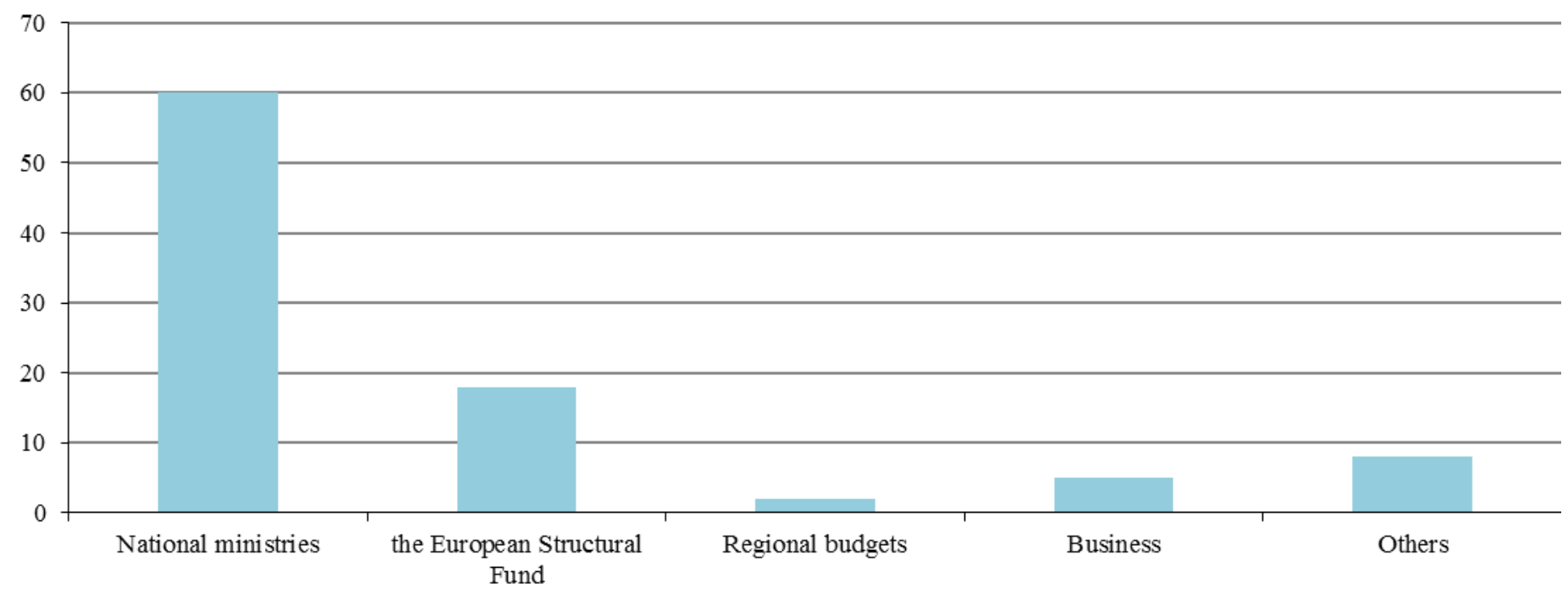

Figure 1. The financial structure of European cluster programs Source: (Kutsenko, 2015). 


\section{ENTREPRENEURSHIP AND SUSTAINABILITY ISSUES}

ISSN 2345-0282 (online) http://jssidoi.org/jesi/ 2019 Volume 7 Number 1 (September) http://doi.org/10.9770/jesi.2019.7.1(42)

The process of clusters' creation was carried out most intensively since 2000 . In particular 500 clusters were created in Europe, North America, New Zealand and Australia in 2003; there were already 1,400 clusters in 2005. During this period, the growth rate of clusters in the world exceeded 100\% (Cluster policy: foreign experience, n.d.). The data of the European Cluster Observatory on clusters' development indicate that the maximum number of clusters was created from 2007 to 2010, e.g. 50 clusters were created in 2007 (Global Cluster Initiative Survey, 2012, p.8).

At present, it is noted that clusters in their development have gone through several stages, while their innovative orientation has steadily been increased. As a result, the most progressive cluster type has appeared - the regional innovation cluster (Regional-sectoral approach to assessing economic growth, n.d.; Rekord, 2012).

Modern clusters are considered to be an important element in the most countries' economic development. Cluster structures have great potential for practical development and implementation of innovations. Therefore, modern innovative development is impossible without examining the clusters' role in this process; in particular, the study of directions for clusters' improvement in order to increase their innovativeness is of considerable theoretical and practical interest (Tvaronavičienė, 2017; Razminienė, Tvaronavičienė, 2017; Monni et al., 2017; Jankowiak, 2018; Petrenko et al., 2019; Amraoui et al., 2019; Bublienė et al., 2019).

Thus, the problematics is that it is necessary to identify directions for improving clusters in order to increase their innovativeness and form a system of indicators to quantify recommended activities.

As the research hypothesis, it is proposed to use the most active and successful directions of clusters' development. As a result of the research it is necessary to identify a set of measures for their implementation in each direction. So a structured system of cluster development elements is formed, which allows increasing innovativeness and developing indicators for evaluating individual measures for the development of cluster's innovativeness.

\section{Methods}

It is noted that innovation activity of firms increases in clusters. The data on firms' innovation activities that depend on participation in clusters is presented in Figure 2 (based on examples of the EU countries).

The analysis of firms' innovation activities showed that companies that are within cluster structures are more innovatively active and successful compared to firms that are outside them because of:

- creation of new or improved products and services;

- creation of new or improved production capacity;

- market research of new products and services;

- triple helix use;

- international trademarks registration;

- application for patents.

Two main trends in modern cluster development are identified by researchers (Rekord, 2010, p. 35; European Commission, n.d.; Markkula, n.d.): 
- intersectoral interaction and cooperation of clusters at the regional and interregional level, which allow strengthening integration processes, expanding the range of products produced, increasing their readiness by creating new and developing existing added value chains;

- fuller use of geographical characteristics due to the EU concept of Smart Specialization.

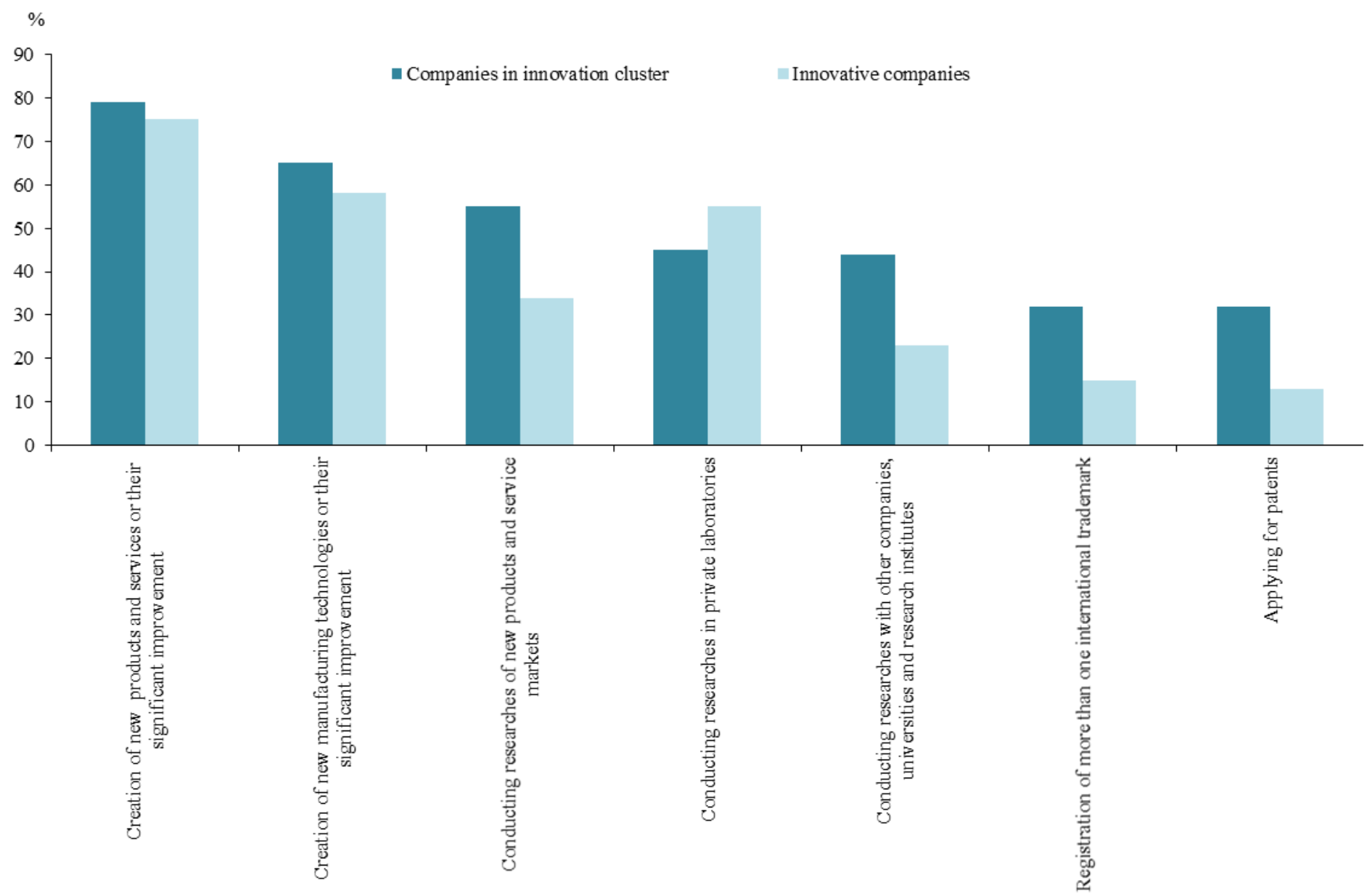

Figure 2. the comparison of firms' innovation activities within and outside cluster structures (for the EU countries) Source: (Innovation and technology clusters of the countries - members of ICSTI, n.d., p. 16).

Smart Specialization concept provides structural changes in a region's activities as a result of the focus on unique industries or types of economic activity. Thus, regional innovation policy in a long-term period is ensured.

The combination of innovation and territorial development aspects in modern clusters can increase competitiveness of individual clusters, regions, and a country as well. The European Commission has determined that modernization of the EU industry should be based on Smart Specialization concept and interregional cooperation. The Smart Specialization Platform was recommended as a tool for implementing this strategy, on the basis of which it is proposed to coordinate clusters' functioning in regions (European Commission, n.d.). 


\section{ENTREPRENEURSHIP AND SUSTAINABILITY ISSUES}

ISSN 2345-0282 (online) http://jssidoi.org/jesi/

2019 Volume 7 Number 1 (September)

http://doi.org/10.9770/jesi.2019.7.1(42)

The EU experience in the European Cluster Improvement Initiative should be particularly noted. Since 2009 it has allowed analyzing clusters' states in the EU and developing recommendations for improvements. For this purpose the European Secretariat for Cluster Analysis was created, which assesses clusters and establishes their correspondence according to three levels (gold, silver and bronze management standards).

Developing countries and countries with economies in transition also participate in cluster programs (for example, the UNIDO Cluster and the Networking Development programs). Their initial goal is to fight poverty through industrial development as a result of selection and clusters' maintenance.

The comparison of clustering rates of the world's leading countries and Russia shows a lag of the Russian economy in this direction. The data presented at the World Economic Forum indicates that from 2008 to 2013 Italian, Finnish, American and German clusters were successfully developed in that period. While the indicators of China, Russia and Kazakhstan have deteriorated by 2013 and the ratings of Russia and Kazakhstan shifted from the 100th to the 120th place (Glukhova, 2012). In this connection serious measures were taken in Russia to accelerate clustering of the country's industry. In 2012 the implementation of the state program for creation and development of 25 pilot regional innovation clusters was launched.

Currently 11 out of 25 pilot Russian clusters specialize in new industries (information technologies, biopharmaceutics and new technologies), 14 clusters are formed on the basis of powerful existing industrial enterprises in the field of nuclear radiation technologies, aerospace and shipbuilding, chemistry and petrochemistry, etc, and also on the basis of small companies, often founded by these enterprises.

The regional structure analysis of the pilot clusters 'distribution showed that $71.4 \%$ of clusters are located in the regions which have large values of the Global Innovation Policy Index. This provided a high-quality innovation base for developing and implementing innovations and training personnel in clusters. In 20154 Russian clusters (Nuclear Innovation Cluster, Dimitrovgrad, Ulyanovsk Region; Kamsky Innovative Territorial and Production Cluster, Republic of Tatarstan; Innovative Territorial Cluster "Zelenograd", Moscow; Innovative Territorial Aerospace Cluster, Samara Region) received the EU Bronze Standard.

The innovative focus of state financial support for a pilot program, particularly in the form of subsidies to the innovation clusters' infrastructure, should be noted as well as advanced training and retraining of personnel and methodological, organizational, expert-analytical and informational support for clusters. The financing of these directions amounted to $65.8 \%$ of the total expenditures spent from the federal budget for the creation and development of pilot regional innovation clusters.

It is noted that a standard Russian cluster in general corresponds to a mature cluster (Ministry of Economic Development of the Russian Federation, n.d.). At the same time Russian clusters need further development and improvement. In particular, foreign experience shows that a competitive cluster should have in its composition (European Cluster Excellence Initiative, 2015):

- $90 \%$ of officially registered participants;

- $45 \%$ of commercial organizations working in the field of cluster's specialization;

- at least $20-15 \%$ of interacting participants;

- operation period of a management company must be at least 2 years.

Foreign experience confirms that for successful innovation diffusion, a cluster must have at least 30-50 specialized firms. The EU standards suggest that a modern innovation cluster should cooperate with universities 


\section{ENTREPRENEURSHIP AND SUSTAINABILITY ISSUES}

ISSN 2345-0282 (online) http://jssidoi.org/jesi/ 2019 Volume 7 Number 1 (September) http://doi.org/10.9770/jesi.2019.7.1(42)

and research centers. That is the triple helix model, a set of interactions between business, science and government.

The process of innovative development is constantly being improved: there is a change in methods and techniques of developing and commercializing innovative products, the number of people participating in innovative activities is also increasing (Novikova et al., 2016; Anisimov et al, 2017; Kiselev, 2015; Morkovkin et al., 2017; Nosova et al, 2018a; Nosova et al, 2018b; Nosova et al, 2018c).

To characterize the innovation rating of individual countries, the Global Innovation Index is currently used. In 2017 top 15 countries in this ranking are European countries, they lead at least in half of the indicators included in the index, which is formed from 84 indicators, including 57 input indicators characterizing a country's innovative potential and 27 output indicators describing an effective use of this potential. The methodology for studying this index is constantly changing and improving, i.e. new indicators are added to separate groups. The formation of these index indicators is based on both statistical and survey data. In this regard the definition of the Global Innovation Index is a rather complicated procedure.

Therefore, a system of indicators reflecting the main directions of improving innovative activities can be used to characterize the results of clusters' functioning.

The proposed directions for cluster improvement in order to increase innovativeness are shown in Figure 3:

- development of cluster's innovation infrastructure;

- increase in cluster's membership;

- development of educational infrastructure;

- management improvement.

The measures for each direction implementation have been identified.

The development of cluster's innovation infrastructure based on the triple helix concept provides:

- involvement of universities in cluster's research activities, on the basis of which research centers and other similar organizations are created (Oganisjana et al., 2017; Girdzijauskaite et al., 2019);

- creation and development of specialized innovation organizations like science parks, business incubators, engineering and other centers.

So, the interaction of business, science and government structures in the form of various development institutions created at the state level, and innovation structures that are actively being formed at the regional level are ensured.

The increase in cluster's membership is proposed to be implemented with:

- increasing a number of majors and commercial organizations operating in cluster's specialization field;

- fuller use of small business forms.

This approach ensures a maximum involvement of firms specializing in a particular field, rapid development and exchange of innovations between them, as well as a use of new forms of innovative interaction. 
The development of educational infrastructure allows improving employees' qualification and carrying out their retraining in order to ensure that qualification level of cluster personnel meets the requirements of innovative development.

Cluster management can be improved on the basis of creating a company managing a cluster, cluster's development centers and other structures that allow cluster participants to interact with each other to increase innovativeness (Novoselov et al., 2017; Sidorova et al., 2018). It should also be noted that territorial innovative clusters allow solving a problem of natural resource management (Kostygova, 2016; Kostygova, 2017; Kostygova, 2018).

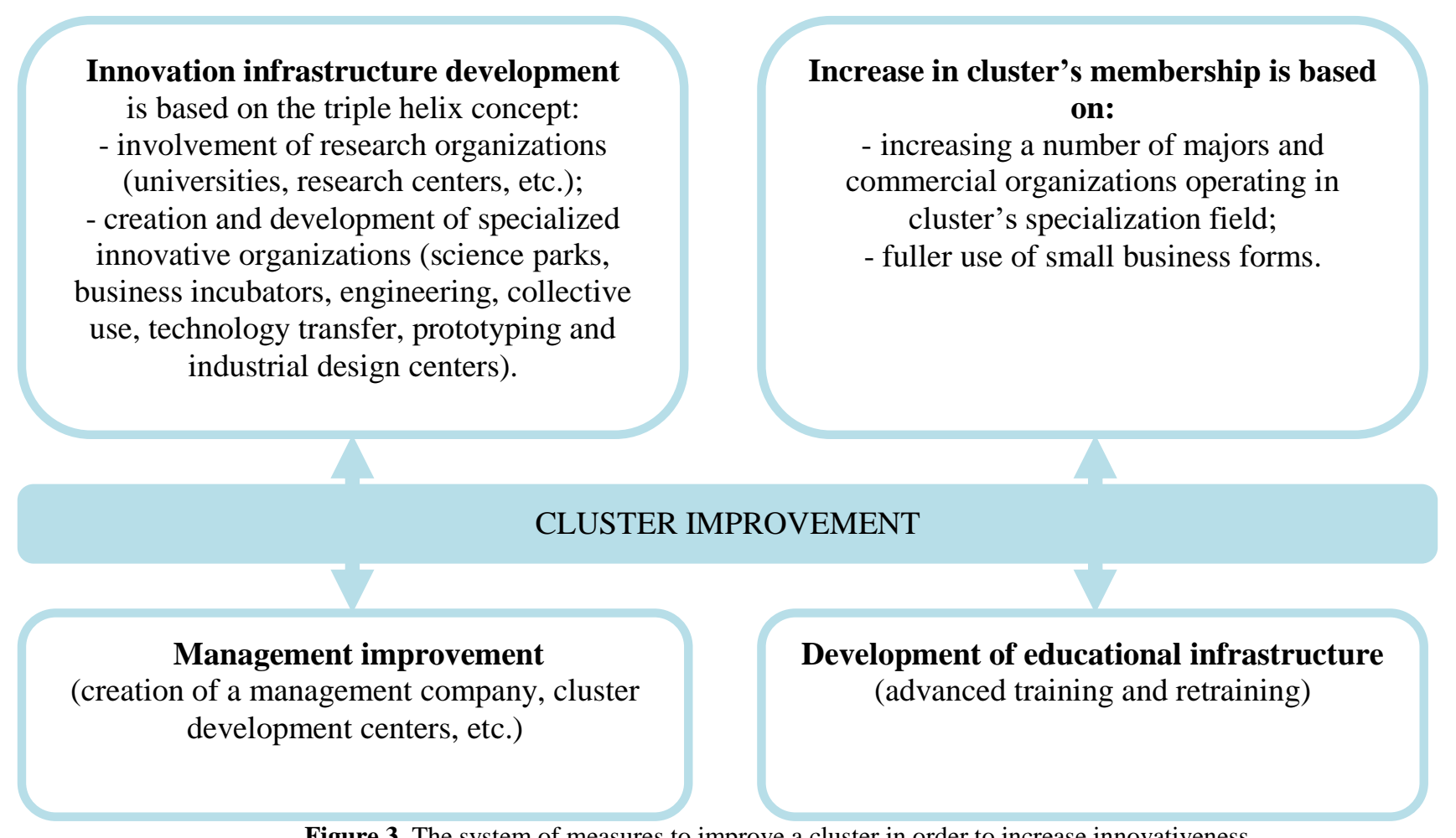

Figure 3. The system of measures to improve a cluster in order to increase innovativeness. Source: Compiled by authors

The implementation of these directions should lead to an increase in the level of cluster's innovative activities. It is necessary that indicators reflecting this process focus on increasing innovative activity of cluster's members reflect the increase in innovative products output, products with higher value added, export and importsubstituting products.

To assess the results obtained it is proposed to use the following system of indicators:

- the period from innovations' development to their implementation into production, years, months;

- the number of innovative organizations of regional, interregional and national level cooperating with a cluster, units;

- the share of cluster's members engaged in innovation activities in the total number of cluster's members, $\%$;

- the availability of training and retraining personnel systems for cluster's members;

- the existence of a cluster management company, cluster development centers and other similar innovative structures; 
- the share of innovative products in the total cluster's output, $\%$;

- the share of higher added value products in the total cluster's output, $\%$;

- the share of export and import-substituting products in the total cluster's output, $\%$.

\section{Results}

In The comparison of the indicators values determines the degree of increase in innovation development, both in a cluster and in individual directions of development. The characteristics of cluster's innovation activities using the example of the Russian titanium cluster's activity and its expected results are shown in Table 1.

Table 1. The characteristics of the cluster's innovation activity (based on examples of the Russian titanium cluster's activity and its expected results by 2024)

\begin{tabular}{|c|c|}
\hline Indicator & Indicator value \\
\hline Period from innovations' development to their implementation into production, years & $1-3$ \\
\hline Number of innovative organizations of regional, interregional and national level cooperating with a cluster, units; & $10-15$ \\
\hline Share of cluster's members engaged in innovation activities in the total number of cluster's members, $\% ;$ & at least 55 \\
\hline Availability of training and retraining personnel systems for cluster's members; & + \\
\hline $\begin{array}{c}\text { Existence of: } \\
\text { - cluster development centers }\end{array}$ & + \\
\hline Share of innovative products in the total cluster's output, $\% ;$ & up to 70 \\
\hline Share of higher added value products in the total cluster's output, $\% ;$ & up to 70 \\
\hline
\end{tabular}

Source: Compiled by authors

\section{Discussion}

Using the proposed system of measures to improve clusters' innovativeness allowed forming the system of indicators to assess innovativeness. In contrast to international experience, based on the use of the Global Innovation Index to characterize the innovation rating of individual countries, the approach recommended by the authors allows us to assess the innovative development level of a particular cluster in individual directions and activities. The recommended system of measures and indicators allows deepening, specifying and evaluating individual measures for the cluster's innovative development. As shown by the study performed, according to the proposed methodology the results obtained for the Russian titanium cluster provide a detailed assessment of innovativeness. As a result the level and directions of further innovative development of a specific cluster were determined.

According to the data presented in Table 1, it follows that the Russian titanium cluster should correspond to the level of a mature cluster by 2024, providing the share of innovative higher added value products in the total cluster's output at the level of $70 \%$. It is also assumed that the share of export products will be $60-70 \%$. The cluster already has a management company and a number of cluster development centers. A system of personnel training and retraining has been implemented and it will be developed. The cluster is expected to cooperate with at least 15 innovative organizations at the regional, interregional and national levels (development institutions of Sverdlovsk region, the Skolkovo Center for Development and Commercialization of New Technologies, the 
Technology Platform “Technologies in Metallurgy and Advanced Materials", etc.). The share of cluster's members engaged in innovation activities in the total number of cluster's members (at least 55\%) should be significantly increased. The results show that Russian clusters can achieve a high level of innovation activity that will reduce the period from development to implementation into production up to 1 year.

\section{Conclusions}

As a result of the study, the following results were obtained:

1. Currently clusters are an integral part of modern economic development of most countries. A modern cluster has a significant potential. An important task was solved in the work, i.e. measures to improve a cluster were systematized in order to increase innovativeness. On this basis, the system of indicators for the quantitative assessment of individual directions of cluster's innovation development has been proposed. These directions include:

- development of cluster's innovation infrastructure;

- increase in cluster's membership;

- development of educational infrastructure;

- management improvement.

2. Moreover for each recommended directions a set of measures necessary for their implementation was proposed. To assess the results obtained in the work, a system of cluster's development indicators was proposed:

- the period from innovations' development to their implementation into production, years;

- the number of innovative organizations of regional, interregional and national level cooperating with a cluster, units;

- the share of cluster's members engaged in innovation activities in the total number of cluster's members, $\%$;

- the availability of training and retraining personnel systems for cluster's members;

- the existence of a cluster management company, cluster development centers and other similar innovative structures;

- the share of innovative products in the total cluster's output, $\%$;

- the share of higher added value products in the total cluster's output, $\%$;

- the share of export and import-substituting products in the total cluster's output, $\%$.

3. The significance of the obtained results lies in development and concretization of methodological guidelines for the study and measures evaluation to increase clusters' innovativeness. Using the example of the Russian innovation titanium cluster, separate directions of its development are evaluated and a possibility of achieving a high level of innovation by Russian clusters is also proved. 


\section{ENTREPRENEURSHIP AND SUSTAINABILITY ISSUES}

ISSN 2345-0282 (online) http://jssidoi.org/jesi/ 2019 Volume 7 Number 1 (September)

http://doi.org/10.9770/jesi.2019.7.1(42)

\section{References}

Abashkin, V. Francuzskie uroki dlja pilotnyh klasterov v Rossii [French lessons for pilot clusters in Russia]. Retrieved June 17, 2018 from: http://issek.hse.ru/news/141026538html

Amraoui, B., Ouhajjou, A., Monni, S., El Amrani El Idrissi, N., Tvaronavičienè, M. 2019. Performance of clusters in Morocco in the shifting economic and industrial reforms, Insights into Regional Development, 1(3): 227-243. https://doi.org/10.9770/ird.2019.1.3(4)

Anisimov, A., Polozhentseva, Y., Zhaglovskaya, A., Aleksakhin, A., 2017. Regional monitoring of staffing support in the coal mining industry. Eurasian Mining, 2: 53-56.

Bublienė, R., Vinogradova, I., Tvaronavičienė, M., Monni, S. 2019. Legal form determination for the development of clusters` activities, Insights into Regional Development, 1(3): 244-258. https://doi.org/10.9770/ird.2019.1.3(5)

Davidenko, E. 2013. Klasterizacija kak instrument realizaciikonkurentnyh preimushhestv stran na mirovom rynke [Clustering as a tool for the implementation of competitive advantages of countries in the world market]. Jekonomicheskie nauki [Economic sciences], 4 (101):179182. (in Russian)

European Cluster Excellence Initiative. 2015. The quality label for cluster organisations - criteria, processes, framework of implementation. Retrieved February 8, 2015. Available at: http://www.cluster-excellence.eu

European Commission. N.D. Available at: https://ec.europa.eu/growth/industry/innovation_en

Fattakhov, R.V., Stroev, P.V., Nizamutdinov, M.M. 2018. Modeling of urban resettlement in Russia: trends and prospects. Financial and Economic Tools Used in the World Hospitality Industry Proceedings of the 5th International Conference on Management and Technology in Knowledge, Service, Tourism and Hospitality: 97 - 102.

Girdzijauskaite, E., Radzeviciene, A., Jakubavicius, A. 2019. Impact of international branch campus KPIs on the university competitiveness: FARE method, Insights into Regional Development, 1(2): 171-180. https://doi.org/10.9770/ird.2019.1.2(7)

Global Cluster Initiative Survey 2012. Survey Summary Report. European Commission, European Cluster Observatory. Stockholm: 8 - 9.

Glukhova, M. 2012. Klastery - nuzhny li oni rossijskoj jekonomike? [Clusters - Do They Need the Russian Economy?] Promyshlennik Rossii [Russian Industrialist]. Available at: http://www.promros.ru/magazine/2012/oct/mariya-gluhovaklastery-nuzhny-li-oni-rossijskojekonomike.phtml

Innovacionno-tehnologicheskie klastery stran - chlenov MCNTI (Innovation and technology clusters of the countries - members of ICSTI) 2013. Available at: http://www.icsti.su/uploaded/201304/cluster.pdf

Jankowiak, A.H. 2018. Cluster Policy Models in the VISEGRAD Group Countries - A Comparative Study, Transformations in Business \& Economics, 17, (2A) (44A): 447-465

Kiselev, B.G. 2015. Innovation development strategy of industrial enterprise (on example of refineries). Tsvetnye Metally, 7: 24 - 28

Klasternaja politika: zarubezhnyj opyt (Cluster policy: foreign experience). 2014. Strategy Journal. Available at: http://strategyjournal.ru/news/promyshlennost/klasternaya-politika-zarubezhnyj-opyt/

Kostygova, L. 2016. Natural resource management in a territorial innovation cluster, 16th international multidisciplinary scientific geoconference SGEM 2016, Ecology, economics, education and legislation conference proceedings, VOLUME III, 30 June - 6 july, 2016 Albena, Bulgaria: 381-388

Kostygova, L. 2017. Ration consumption of natural resources based on additive technologies in the titanium production, 17th international multidisciplinary scientific geoconference SGEM 2017, Ecology, Economics, Education and Legislation ISSUE 5.329, June - 5 july, 2017 Albena, Bulgaria: 695-699 


\section{ENTREPRENEURSHIP AND SUSTAINABILITY ISSUES}

ISSN 2345-0282 (online) http://jssidoi.org/jesi/ 2019 Volume 7 Number 1 (September) http://doi.org/10.9770/jesi.2019.7.1(42)

Kostygova, L. 2018. Prospects for implementing a circular economy in industry based on territorial innovative clusters, 18th international multidisciplinary scientific geoconference SGEM 2018, Ecology, Economics, Education and Legislation ISSUE 5.3, 29, 2 July - 8 July, 2018 Albena, Bulgaria: 631-638

Kutsenko, E. 2015. Pilotnye innovacionnye territorial'nye klastery Rossii: model' ustojchivogo razvitija [Pilot innovative territorial clusters of Russia: a model of sustainable development]. Foresight, 1. Retrieved February 6, 2018 from: https://foresight-journal.hse.ru

Lenchuk, E. Klasternyj podhod v strategii innovacionnogo razvitija Rossii [Cluster approach to the strategy of Russian innovative development]. Jekonomicheskij portal [Economic portal]. Retrieved October 10, 2018 from: http://institutiones.com/strategies1979klasternyj-podxod-v-...html

Markkula M. Making smart regions smarter: smart specialization and the role of universities in regional innovation ecosystems. Retrieved June 10, 2018 from: www.elexpro.ru/932.php

Marshall A. 1983. Principy politicheskoj jekonomii [Principles of political economy]. Moscow, Progress Publ.

Ministry of Economic Development of the Russian Federation. Implementation of cluster policy in the Russian Federation. Retrieved January 15, 2018 from: http://www.slideshare.net/semenvuymenkov/ss-48825963

Monni, S., Palumbo, F., Tvaronavičienė, M. 2017. Cluster performance: an attempt to evaluate the Lithuanian case. Entrepreneurship and Sustainability Issues, 5(1): 43-57. http://doi.org/10.9770/jesi.2017.5.1(4)

Morkovkin, D., Shmanev, S., Shmaneva, L. 2017. Problems and Trends in Innovative Transformation of Russian Economy and Infrastructure Development. Advances in Economics, Business and Management Research, volume 32. 3rd International Conference on Economics, Management, Law and Education (EMLE 2017). Atlantis Press: 25-35.

Nosova, S.S, Makar, S.V., Chaplyuk, V. Z., Medvedeva, A. M., Semenova, A., N. 2018c. Collaborative Nature of Innovative Economy Naturaleza colaborativa de la economía innovadora. Espacios, 39(41): 32-41.

Nosova, S.S, Norkina, A.N., Makar, S.V., Arakelova, I.V., Medvedeva, A. M., Chaplyuk, V. Z. 2018b. The digital economy as a new paradigm for overcoming turbulence in the modern economy of Russia. Espacios, 39(24): 27.

Nosova, S.S., Meshkov, S.A., Meshkova, G.V., Stroev, P.V., Boyar-Sozonovitch, A.S. 2018a. Digital technologies as a new vector in the growth of innovativeness and competitiveness of industrial enterprises. International Journal of Civil Engineering and Technology, 9(6):1411-1422.

Novikova, N., Barmuta, K., Kaderova, V., Il'Yaschenko, D., Abdulov, R., Aleksakhin, A. 2016. Planning of new products technological mastering and its influence on economic indicators of companies. International Journal of Economics and Financial Issues, 6(8S): 65 - 70.

Novoselov, S.N., Larina, S.V., Klimovskikh, N.V., Gorlova, E.A., Aleksakhina, Y.V., Shedko, Y.N. 2017. Becoming and Growth of Cluster Management in the Regional Economy of Russia. International Journal of Applied Business and Economic Research, 15(12): 93101

Oganisjana, K., Svirina, A., Surikova, S.; Grīnberga-Zālīte, G., Kozlovskis. K. 2017. Engaging universities in social innovation research for understanding sustainability issues. Entrepreneurship and Sustainability Issues, 5(1): 9-22. http://doi.org/10.9770/jesi.2017.5.1(1)

Petrenko, Y.; Vechkinzova, E.; Antonov, V. 2019. Transition from the industrial clusters to the smart specialization of the regions in Kazakhstan, Insights into Regional Development, 1(2): 118-128. https://doi.org/10.9770/ird.2019.1.2(3)

Porter, M. 2005. Konkurencija [Competition]. Moscow, Williams Pabl.

Razminienè, K., Tvaronavičienè, M. 2017. Economic globalization and its impacts on clustering, Terra Economicus, 15 (2): $109-121$ http://doi.org/10.23683/2073-6606-2017-15-2-109-121 clustering.html

Regional'no-otraslevoj podhod k ocenke jekonomicheskogo rosta (Regional-sectoral approach to assessing economic growth). Market journal. Available at: http://www.market-journal.com/problemieco/11.html 


\section{ENTREPRENEURSHIP AND SUSTAINABILITY ISSUES}

ISSN 2345-0282 (online) http://jssidoi.org/jesi/ 2019 Volume 7 Number 1 (September) http://doi.org/10.9770/jesi.2019.7.1(42)

Rekord, S. 2010. Razvitie promyshlenno-innovacionnyh klasterov v Evrope: jevoljucija i sovremennaja diskussija [The development of industrial innovation clusters in Europe: the evolution and modern discussion]. St. Peterburg, St. Petersburg State University of Economics and Finance Publ.

Rekord, S. 2012. Razvitie promyshlenno-innovacionnyh klasterov v kontekste jevoljucionnoj jekonomiki [The development of industrial innovation clusters in the context of an evolutionary economy]. Vestnik Rossijskoj akademii estestvennyh nauk [Bulletin of the Russian Academy of Natural Sciences], 2: 34-37.

Sidorova, E., Muradov, I. 2018. Formation of an effective corporate governance system for industrial interprises, 17th international multidisciplinary scientific geoconference SGEM 2018, Ecology, Economics, Education and Legislation ISSUE 5.3, 2 July - 8 July, 2018 Albena, Bulgaria: 407-414.

Tvaronavičienė, M., Razminienè K. 2017. Towards competitive regional development through clusters: approaches to their performance evaluation. Journal of Competitiveness, 9(4): 133-147, https://doi.org/10.7441/joc.2017.04.09

Tvaronavičienè, M. 2017. Clusters, innovations and energy efficiency: if relantionship could be traced. Marketing and Management of Innovations, 2: 382-391. http://doi.org/10.21272/mmi.2017.2-35

\section{Lyudmila KOSTYGOVA}

ORCID ID: 0000-0001-7303-8075

\section{Elena SIDOROVA}

ORCID ID: 0000-0002-4385-7173

\section{Natalia VIKHROVA}

ORCID ID: 0000-0001-5865-3969 